\title{
Hubungan Merokok dan Konsumsi Kopi dengan Tekanan Darah pada Pasien Hipertensi
}

\author{
M. Ramadhani Firmansyah ${ }^{1}$, Rustam ${ }^{2}$ \\ ${ }^{1,2}$ Program Studi NERS, STIK Siti Khadijah Palembang \\ Email: ramadhanifirmansyah@yahoo.com
}

\begin{abstract}
The Correlation Between Smoking and Consumption Coffee to Blood Sugar Level on Hypertension Patient. Hypertension is a situation where blood pressure someone was sitting on normal. Hypertension ranked 1 of 14 not an infectious disease at Public Health Centre Pembina Palembang in 2015, as much as 3054. Risk factors cause hypertension there are a smoking habit and consumption coffee. This study aims to understand relations smoking and consumption coffee toward blood pressure on a patient hypertension at Public Health Centre Pembina Palembang in 2016. The research is quantitative analytic survey through cross sectional approach.The total number of respondents were 68 respondents through purposive sampling technique.Analysis of data in this study using chi-square statistic. This research result indicates that there was a smoking ( $\mathrm{p}$-value $=0.014)$ and consumption coffee $(\mathrm{p}$-value=0.017) with blood pressure in a patient hypertension public Health Centre Palembang in 2016. It's hoped that the patient's hypertension should quit smoking and consumption coffee, so should improve the standard of health and lowered the incidence of Hypertension.
\end{abstract}

Keywords: Hypertension, Smoking, Consumption of coffee

\begin{abstract}
Abstrak: Hubungan Merokok dan Konsumsi Kopi dengan Tekanan Darah pada Pasien Hipertensi. Hipertensi merupakan suatu keadaan dimana tekanan darah seseorang berada di atas normal. Hipertensi menduduki peringkat 1 dari 14 Penyakit Tidak menular (PTM) di Puskesmas Pembina Palembang yaitu berjumlah 3054 pada tahun 2015. Faktor resiko penyebab hipertensi antara lain Kebiasaan merokok, dan konsumsi kopi. Penelitian ini bertujuan untuk mengetahui hubungan merokok dan konsumsi kopi dengan tekanan darah pada pasien hipertensi di Puskesmas Pembina Palembang tahun 2016.Jenis penelitian ini adalah Kuantitatif yang bersifat Survey Analitik dengan menggunakan pendekatan Cross Sectional.Jumlah responden sebanyak 68 responden di ambil dengan teknik Pusposive Samping. Analisis data dalam penelitian ini menggunakan metode Chi-square. Hasil penelitian ini menunjukkan bahwa ada Hubungan merokok ( $p$-value $=0,014)$ dan Konsumsi kopi $(p$-value $=0,017)$ dengan tekanan darah pada pasien Hipertensi di Puskesmas Pembina Palembang tahun 2016. Diharapkan pasien hipertensi dapat berhenti merokok, dan konsumsi kopi, sehingga dapat meningkatkan derajat kesehatan serta dapat menurunkan angka kejadian Hipertensi.
\end{abstract}

Kata kunci: Hipertensi, Merokok, Konsumsi kopi

Penyakit degeneratif menjadi pembicaraan hangat di berbagai media massa. Penyakit ini bahkan bukan hanya menjadi pembicaraan kalangan praktisi kesehatan, tetapi sudah menjadi pembicaraan bagi khalayak umum. Penyebab utama yang mempercepat munculnya penyakit degeneratif adalah Gaya Hidup yang tidak sehat. Salah satu penyakit degeneratif tersebut adalah Hipertensi (Khasanah, 2012).

Hipertensi merupakan suatu keadaan dimana tekanan darah seseorang berada di atas normal, atau optimal yaitu $120 \mathrm{mmHg}$ untuk sistolik dan $80 \mathrm{mmHg}$ untuk diastolik. Hipertensi yang terjadi dalam jangka lama dan terus menerus bisa memicu terjadinya stroke, serangan jantung, gagal jantung, dan merupakan penyebab utama gagal ginjal kronik (Rudianto, 2013).

World Health Organization (WHO, 2011) menunjukkan bahwa sekitar 972 juta orang atau $26.4 \%$ di dunia mengidap hipertensi dan akan terus meningkat menjadi 29,2\% pada tahun 2025 . Hipertensi merupakan salah satu penyebab kematian di dunia, terdapat 7 juta orang meninggal dunia akibat hipertensi.

Hipertensi masih menjadi tantangan besar di Indonesia. Obat-obatan efektif banyak tersedia, namun angka penderita tetap meningkat. Padahal hipertensi merupakan faktor utama kerusakan otak, ginjal dan jantung jika tidak terdeteksi sejak dini. Data dari Perhimpunan Dokter Hipertensi Indonesia (InaSH) menyebutkan bahwa faktor 
kematian paling tinggi adalah hipertensi, menyebabkan kematian pada sekitar 7 juta penduduk Indonesia (InaSH, 2014).

Menurut Kemenkes RI Pada tahun 2013 hipertensi merupakan 10 penyakit terbesar di Indonesia yang menempati peringkat pertama. Pada tahun 2012 sebanyak 43,2\% dari total penduduk Indonesia yang menderita hipertensi, dan pada tahun 2013 terjadi peningkatan Penderita hipertensi menjadi $45,9 \%$ dari total seluruh penduduk Indonesia. Jika saat ini jumlah penduduk Indonesia sebesar 252.124.458 jiwa maka terdapat 65.048.110 jiwa yang menderita hipertensi (Kemenkes RI, 2013).

Penyakit hipertensi merupakan penyakit tidak menular (PTM) yang menduduki peringkat pertama di provinsi sumatera selatan. Prevalensi penderita hipertensi pada tahun 2013 sebanyak 62858 jiwa, ditahun 2014 tercatat sebanyak 70426 jiwa yang menderita hipertensi, dan tahun 2015 sebanyak 79192 jiwa penderita hipertensi (Dinkes Sumatera Selatan, 2016).

Berdasarkan data yang diperoleh dari Dinas Kesehatan Kota Palembang. Penderita Hipertensi tahun 2013 berjumlah 62.858 jiwa, pada tahun 2014 berjumlah 70.426 jiwa, dan pada tahun 2015 berjumlah 79.192 jiwa (Dinkes Kota Palembang, 2015).

Berdasarkan data yang diperoleh dari profil Puskesmas Pembina palembang. Kasus Hipertensi menduduki peringkat 1 dari 14 Penyakit Tidak Menular (PTM) lainnya di puskesmas Pembina. Penderita hipertensi pada tahun 2014 berjumlah 2871 penderita, sedangkan pada tahun 2015 sebanyak 3054 penderita hipertensi (Profil Puseksmas Pembina, 2015).

Beberapa faktor resiko yang dapat menyebabkan hipertensi yaitu faktor yang tidak dapat dimodifikasi antara lain usia lanjut, adanya riwayat tekanan darah tinggi dalam keluarga, dan Jenis kelamin, faktor yang dapat dimodifikasi antara lain kelebihan berat badan yang diikuti dengan kurangnya olahraga, merokok, konsumsi alkohol, konsumsi kopi dan natrium (Palmer, 2007).

Terjadinya hipertensi disebabkan oleh beberapa faktor yang saling mempengaruhi, dimana faktor utama yang berperan dalam patofisiologi adalah faktor yang dapat dimodifikasi yaitu Merokok dan Kopi (Endang, 2014).

Rokok mengandung ribuan zat kimia berbahaya bagi kesehatan tubuh, diantaranya yaitu tar, nikotin, dan karbon monoksida. Zat kimia tersebut yang masuk ke dalam aliran darah dapatr merusak lapisan endotel pembuluh darah arteridan mengakibatkan proses aterosklerosis dan hipertensi (Nurkhalida, 2003). Seseorang merokok dua batang maka tekanan sistolik maupun diastolikakan meningkat $10 \mathrm{mmHg}$. Tekanan darah akan tetap pada ketinggian ini sampai 30 menit setelah berhenti menghisap rokok. Sedangkan untuk perokok berattekanan darah akan berada pada level tinggi sepanjang hari (Sheldon, 2005).

Pengaruh kopi terhadap terjadinya hipertensi saat ini masih kontroversial. Kopi mempengaruhi tekanan darah karena mengandung polifenol, kalium, dan kafein. Kafein memiliki efek yang antagonis kompetitif terhadap reseptoradenosin. Adenosin merupakan neuromodulator yang mempengaruhi sejumlah fungsi pada susunan saraf pusat. Hal ini berdampak pada vasokonstriksi danmeningkatkan total resistensi perifer, yang akan menyebabkan tekanan darah. Kandunagan kafein pada secangkir kopi sekitar 80-125 mg (Palmer,2007).

Berdasarkan penelitian yang pernah dilakukan oleh Ainun (2012) tentang hubungan gaya hidup dengan kejadian hipertensi pada mahasiswa di lingkup kesehatan Universitas Hasanuddin. Hasil penelitian diperoleh variabel yang berhubungan dengan hipertensi adalah perilaku merokok ( $p$ value $=0,000)$, kebiasaan olahraga ( $p$-value $=0,028$ ), konsumsi kopi ( $p$-value $=0,000)$, dan konsumsi alkohol (p-value $=0,002)$. Variabel yang tidak berhubungan dengan hipertensi adalah stres ( $p$ value $=0,089$ ). Kesimpulan dari penelitian bahwa ada hubungan perilaku merokok, kebiasaan olahraga, konsumsi kopi, konsumsi alkohol dengan kejadian hipertensi pada mahasiswa Universitas Hasanuddin.

Hasil Penelitian juga dilakukan oleh Syarwendah (2014) tentang hubungan gaya hidup dengan tekanan darah pada pasien Hipertensi di poliklinik penyakit dalam RSI Siti Khadijah Palembang, hasilnya ada hubungan antara kebiasaan merokok dengan tekanan darah pada pasien hipertensi ( $p$-value $=0,013$ ). Ada hubungan antara aktivitas fisik dengan tekanan darah pada pasien Hipertensi ( $p$-value $=0,013$ ), tidak ada hubungan antara konsumsi alkohol dengan tekanan darah pada pasien hipertensi ( $p$-value $=0.544)$. Kesimpulannya adalah Ada Hubungan antara kebiasaan merokok, dan aktivitas fisik dengan tekanan darah pada pasien hipertensi.

Berdasarkan penjelasan di atas diketahui bahwa faktor resiko yang mempengaruhi tekanan darah pasien hipertensi adalah merokok, dan Konsumsi kopi, sehingga peneliti tertarik meneliti hubungan merokok dan konsumsi kopi dengan tekanan darah pada pasien hipertensi di Puskesmas Pembina Palembang Tahun 2016. 


\section{METODE}

Penelitian ini menggunakan metode analitik dengan pendekatan cross sectional dengan tujuan untuk mengetahui hubungan merokok dan konsumsi kopi dengan tekanan darah pada pasien hipertensi. Penelitian ini dilaksanakan di Puskesmas Pembina Palembang pada tanggal pada tanggal 4-9 April 2016. Populasi pada penelitian ini adalah semua penderita hipertensi yang berkunjung ke Puskesmas Pembina Palembang, dan sampel dalam penelitian ini sebanyak 68 responden diambil menggunakan teknik purposive sampling.

HASIL

Tabel 1. Distribusi Frekuensi Karakteristik Responden

\begin{tabular}{lcc}
\hline \multicolumn{1}{c}{ Variabel Penelitian } & n & \% \\
\hline Jenis Kelamin & & \\
Pria & 41 & 60,3 \\
Wanita & 27 & 39,7 \\
\hline Tekanan Darah & & \\
Tidak terkontrol \\
$\begin{array}{l}\text { (TD } \geq 140 / 90 \mathrm{mmHg}) \\
\text { Terkontrol }\end{array}$ & 40 & 58,8 \\
$\begin{array}{l}\text { (TD 120/80-139/89 mmHg) } \\
\text { Kebiasaan Merokok }\end{array}$ & 28 & 41,2 \\
Perokok & & \\
Bukan perokok & 41 & 60,3 \\
\hline Konsumsi Kopi & 27 & 39,7 \\
Mengkonsumsi & & \\
Tidak Mengkonsumsi & 46 & 67,6 \\
\hline
\end{tabular}

Berdasarkan tabel 1 didapatkan hasil bahwa dari 68 orang sebagian besar responden berjenis kelamin laki-laki sebanyak $41(60.3 \%)$ responden, pasien hipertensi yang memiliki tekanan darah tidak terkontrol sebanyak $40(58.8 \%)$ responden, memiliki kebiasaan merokok sebanyak 41 (60,3\%) responden, dan mengkonsumsi kopi sebanyak 46 (67.6\%) responden.

Tabel 2. Hubungan Kebiasaan Merokok dengan Tekanan Darah pada Pasien Hipertensi

\begin{tabular}{|c|c|c|c|c|c|c|}
\hline \multirow{3}{*}{$\begin{array}{c}\text { Kebiasaan } \\
\text { Merokok }\end{array}$} & \multicolumn{4}{|c|}{ Tekanan darah } & \multirow{2}{*}{\multicolumn{2}{|c|}{ Jumlah }} \\
\hline & \multicolumn{2}{|c|}{$\begin{array}{c}\text { Tidak } \\
\text { Terkontrol } \\
\end{array}$} & \multicolumn{2}{|c|}{ Terkontrol } & & \\
\hline & $\mathbf{n}$ & $\%$ & $\mathbf{n}$ & $\%$ & $\mathbf{n}$ & $\%$ \\
\hline Perokok & 29 & 70,7 & 12 & 29,3 & 41 & 100 \\
\hline $\begin{array}{l}\text { Bukan } \\
\text { perokok }\end{array}$ & 11 & 40,7 & 16 & 59,3 & 27 & 100 \\
\hline $\begin{array}{l}p \text {-value } \\
\text { OR }\end{array}$ & & & & & & \\
\hline
\end{tabular}

Berdasarkan tabel 2 diperoleh responden yang perokok dengan tekanan darah tidak terkontrol sebanyak 29 responden (70,7\%), lebih banyak dibandingkan bukan perokok dengan tekanan darah tidak terkontrol yaitu 11 responden $(40,7 \%)$, Hasil analis menggunakan uji Chi-square didapatkan nilai $p$-value $=0,014$, menunjukkan terdapat hubungan yang signifikan antara kebiasaan merokok dengan tekanan darah pada pasien hipertensi .

\section{Tabel 3. Hubungan Konsumsi Kopi dengan Tekanan Darah pada Pasien Hipertensi}

\begin{tabular}{|c|c|c|c|c|c|c|}
\hline \multirow{3}{*}{$\begin{array}{c}\text { Konsumsi } \\
\text { Kopi }\end{array}$} & \multicolumn{4}{|c|}{ Tekanan darah } & \multirow{2}{*}{\multicolumn{2}{|c|}{ Jumlah }} \\
\hline & \multicolumn{2}{|c|}{$\begin{array}{c}\text { Tidak } \\
\text { terkontrol }\end{array}$} & \multicolumn{2}{|c|}{ Terkontrol } & & \\
\hline & $\mathbf{n}$ & $\%$ & $\mathbf{n}$ & $\%$ & $\mathbf{n}$ & $\%$ \\
\hline Mengkonsumsi & 32 & 68,1 & 15 & 31,9 & 47 & 100 \\
\hline $\begin{array}{l}\text { Tidak } \\
\text { mengkonsumsi }\end{array}$ & 8 & 38,1 & 13 & 61,9 & 21 & 100 \\
\hline p-value & \multicolumn{6}{|c|}{0,020} \\
\hline OR & \multicolumn{6}{|c|}{3,467} \\
\hline
\end{tabular}

Berdasarkan tabel 3, diperoleh responden yang mengkonsumsi kopi dengan tekanan darah tidak terkontrol yaitu 32 responden $(68,1 \%)$, lebih banyak dibandingkan responden tidak mengkonsumsi kopi dengan tekanan darah tidak terkontrol sebanyak 8 responden $(38,1 \%)$. Hasil analisis dengan uji Chi-square didapatkan nilai $p$ value $=0,020$ menunjukkan terdapat hubungan yang signifikan antara konsumsi kopi dengan tekanan darah pada pasien hipertensi.

\section{PEMBAHASAN}

Dari hasil penelitian variabel penelitian kebiasaan merokok dengan tekanan darah pada pasien hipertensi didapatkan nilai $p$-value 0,014 $<\alpha(0.05)$, hal ini menunjukan ada hubungan antara kebiasaan merokok dengan tekanan darah pada pasien hipertensi di Puskesmas Pembina Palembang tahun 2016. Nilai $\mathrm{OR}=3,515$, hal ini menunjukkan bahwa pasien yang merokok beresiko 3,515 kali untuk tidak terkontrolnya tekanan darah dibandingkan dengan pasien yang bukan perokok.

Penelitian ini sesuai dengan teori yang dikemukakan oleh Casey \& Benson (2012) mengatakan bahwa ada hubungan antara merokok dengan peningkatan risiko kardiovaskuler, tekanan darah perokok melonjak berkali-kali sepanjang hari selama responden merokok. Sebagai contoh, perokok dengan pre-hipertensi $<140 / 90 \mathrm{mmHg}$ sebenarnya mencapai hipertensi stadium 1 setiap sekali merokok. 
Peningkatan ini terjadi karena nikotin yang menyempitkan pembuluh darah sehingga memaksa jantung bekerja keras dan mengakibatkan tekanan darah meningkat. Rokok mengandung ribuan zat kimia berbahaya bagi kesehatan tubuh, diantaranya yaitu tar, nikotin, dan karbon monoksida. Zat kimia tersebut yangmasuk kedalam aliran darah dapat merusak lapisan endotel pembuluh darah arteridan mengakibatkan proses aterosklerosis dan hipertensi (Nurkhalida, 2003).

Hasil penelitian ini sejalan dengan yang dilakukan oleh Anggraini (2013) dengan judul hubungan karakteristik pasien rawat jalan dengan kejadian hipertensi di wilayah kerja puskesmas padang selasa bahwa ada hubungan kebisaan merokok dengan tekanan darah pasien rawat jalan di Wilayah Kerja Puskesmas Padang Selasa ( $p$-value $=0,006)$.

Hasil penelitian ini juga sejalan dengan Syarwendah (2014) tentang hubungan gaya hidup dengan tekanan darah pada pasien hipertensi di Poliklinik Penyakit Dalam Rumah Sakit Islam Siti Khadijah Palembang, Hasilnya ada hubungan antara kebiasaan merokok dengan tekanan darah pada pasien hipertensi ( $p$-value $=0,013$ ).

Menurut asumsi peneliti

bahwa peningkatan tekanan darah pada perokok disebabkan karena kebiasaan merokok responden yang sudah menjadi kebutuhan sehari-hari, bahkan ada responden bisa menghabiskan lebih dari 20 batang rokok per hari, sehingga akan menyebabkan penumpukan zat berbahaya di dalam darah dan dapat menyebabkan berbagai penyakit salah satunya penyakit kardiovaskuler karena zat nikotin yangmasuk kedalam aliran darah dapat merusak lapisan dinding pembuluh darah arteridan mengakibatkan proses aterosklerosis dan hipertensi.

Hasil penelitian variabel konsumsi kopi pada pasien hipertensi didapatkan nilai $p$ value $0,020<\alpha(0.05)$, hal ini menunjukan ada hubungan antara kebiasaan merokok dengan tekanan darah pada pasien hipertensi di Puskesmas Pembina Palembang tahun 2016. Nilai $\mathrm{OR}=3,467$, hal ini menunjukkan bahwa pasien yang mengkonsumsi kopi beresiko 3,467 kali untuk tidak terkontrolnya tekanan darah dibandingkan dengan pasien yang tidak mengkonsumsi kopi.

Penelitian ini sesuai dengan teori Palmer, (2007). Kopi dapat mempengaruhi tekanan darah karena mengandung Polifenol, Niacin, dan Kafein. Kafein memiliki efek merangsang sistem syarat pusat(SSP), Perangsangan pada SSP menimbulkan perasaan tidak mengantuk,tidak begitu lelah,serta daya pikir lebih cepat dan lebih jernih, tetapisebaliknya kemampuan koordinasi otot, ketepatan waktu dan ketepatanberhitung berkurang. Kafein dapat merangsang pusat vasomotor dan perangsangan langsung miokardium menyebabkan kenaikan tekanan darah. Orang yang tidak mengkonsumsi kopi memiliki tekanan darah yang lebihrendah dibandingkan orang yang mengkonsumsi 1-3 cangkir per hari, dan orang yang mengkonsumsi kopi 3-6 cangkir per hari memiliki tekanan darah tinggi.

Sumber lain juga menyebutkan bahwa kafein mengikat reseptoradenosin di otak. Adenosin ialah nukleotida yang mengurangi aktivitas sel saraf saat tertambat pada sel tersebut. Seperti adenosin, molekul kafein juga tertambat pada reseptor yang sama, tetapi akibatnya berbeda. Kafein tidak akan memperlambat aktivitas sel saraf/ otak, sebaliknya menghalangi adenosin untuk berfungsi. Dampaknya aktivitas otak meningkat dan mengakibatkan hormon adrenalin atau epinefrin terlepas. Hormon tersebut akan menaikkan detak jantung, meninggikan tekanan darah, menambah penyaluran darah ke otot-otot, mengurangi penyaluran darah ke kulit dan organ dalam, dan mengeluarkan glukosa dari hati. Pada dosis tinggi, adrenalin mempunyai efek simpatomimetik yang menonjol yaitu dengan kontraksi semua pembuluh, tahanan periferakan naik dan dengan ini baik tekanan sistolik maupun tekanan diastolikakan naik juga (Siswono, 2001).

Penelitian ini juga sejalan dengan teori James (2004). Efek stimulan kafein tergantung dari kadar kafein dalam plasma. Kenaikan tekanan darah yang terjadi pada setiap penambahan konsumsi kopi (cangkir) berbanding terbalik dengan jumlah kopi yang sudah dikonsumsi. Hal tersebut berarti kenaikan tekanan darah yang terjadisetelah meminum kopi pada cangkir yang kedua atau ketiga akan lebih rendah dibandingkan saat meminum kopi pada cangkir yang pertama. Efek tersebut terjadi karena reseptor adenosin yang ada sudah jenuh dengan konsentrasi kafein dari kopi yang dikonsumsi pertama kali kafein yang dikonsumsi setiap hari hanya menyebabkan efek toleransi secara parsial. Kafein tetap memberikan pengaruh peningkatan tekanan darah, baik pada populasi yang tidak terbiasa minum kopi, peminum ringan, sedang ataupun berat.

Berdasarkan penelitian yang pernah dilakukan oleh Ainun (2012) tentang hubungan gaya hidup dengan kejadian hipertensi pada mahasiswa di lingkup kesehatan Universitas Hasanuddin. Hasil penelitian diperoleh ada hubungan konsumsi kopi ( $p$-value $=0,000)$ dengan kejadian hipertensi pada mahasiswa di Lingkup Kesehatan Universitas Hasanuddin tahun 2012.

Menurut asusmi peneliti peningkatan tekanan darah pada pasien hipertensi dengan konsumsi kopi 
disebabkan karena salah satu zat yang terkandung dalam kopi yaitu kafein yang mengandung zat aditif. Zat ini akan berbahaya bagi penderita Hipertensi. Kafein bekerja di dalam tubuh dengan mengambil alih reseptoradenosin dalam sel saraf yang akan memacu produksi hormon adrenalin dan menyebabkan peningkatan tekanan darah. Kafein tidak akan memperlambat aktivitas sel saraf/ otak, sebaliknya menghalangi adenosin untuk berfungsi. Dampaknya aktivitas otak meningkat dan mengakibatkan hormon adrenalin atau epinefrin terlepas. Hormon tersebut akan menaikkan detak jantung, meninggikan tekanan darah.

\section{SIMPULAN}

Berdasarkan hasil penelitian di Puskesmas Pembina Palembang pada tanggal pada tanggal 4-9 April 2016 diketahui bahwa:

1. Distribusi frekuensi responden dengan tekanan darah tidak terkontrol yaitu 40 responden $(58,8)$, lebih banyak dibandingkan dengan tekanan darah terkontrol yaitu 28 responden $(41,2 \%)$.

2. Distribusi Frekuensi responden dengan kebiasaan merokok yang paling banyak berada di perokok yaitu 41 responden $(60,3 \%)$, dibandingkan dengan bukan perokok yaitu 27 responden $(39,7 \%)$.

\section{DAFTAR PUSTAKA}

Ainun. 2012. Hubungan Gaya Hidup dengan Kejadian Hipertensi pada Mahasiswa di Lingkup Kesehatan Universitas Hasanuddin. Skripsi. Universitas Hasanuddin: Makasar.

Anggraini. 2013. Hubungan Karakteristik Pasien Rawat Jalan dengan Kejadian Hipertensi di Wilayah Kerja Puskesmas Padang Selasa Tahun 2013. Skripsi. STIK Bina Husada. Palembang.

Casey dan Benson. 2012. Menurunkan Tekanan Darah. Jakarta: PT. Bhuana Ilmu Populer.

Dinkes Kota Palembang. 2015. Profil Kesehatan Kota Palembang Tahun 2015.

Dinkes Provinsi Sumatera Selatan. 2016. Profil Kesehatan Provinsi Sumatera Selatan Tahun 2016.

Endang, T. 2014. Pelayanan Keperawatan Bagi Penderita Hipertensi Secara Terpadu, Yogyakarta: Graha Ilmu.

Indonesian Society of Hypertension. 2014. INASH Scientific Meeting Ke-8 dan Tips Hipertensi INASH: Hipertensi Menduduki Penyebab Kematian Pertama di Indonesia.
3. Distribusi frekuensi responden yang mengkonsumsi kopi yaitu 46 responden $(67,6 \%)$, lebih banyak dibandingkan dengan responden yang tidak mengkonsumsi kopi yaitu 22 responden $(32,4 \%)$.

4. Ada hubungan antara kebiasaan merokok dengan tekanan darah pada pasien Hipertensi di Puskesmas Pembina Palembang tahun 2016 ( $p$ value $=0,014)$.

5. Ada hubungan antara Konsumsi Kopi dengan tekanan darah pada pasien Hipertensi di Puskesmas Pembina Palembang tahun 2016 ( $p$ value $=0,020$ ).

\section{SARAN}

Diharapkan kepada pihak Puskesmas Pembina Palembang untuk lebih meningkatkan pelayanan kesehatan terutama peningkatan di bidang Preventif dan Promotif melalui penyuluhan minimal 1 bulan sekali tentang pencegahan penyakit hipertensi agar dapat meningkatkan pengetahuan masyarakat tentang bahaya penyakit hipertensi, serta mencegah komplikasi bagi responden yang berisiko menderita hipertensi maupun yang sudah menderita hipertensi dengan cara menerapkan pola hidup sehat.

James J.E. 2004. Critical Review of Dietary Caffeine and Blood Pressure: A RelationshipThat Should Be Taken More Seriously. Psychosomatic Medicine. 66:63-71.

Kementrian Kesehatan. 2013. Laporan Nasional Riset Kesehatan Dasar (RISKESDAS) 2013. Badan Litbangkes, Depkes RI. Jakarta.

Khasanah, Nur. 2012. Waspadai Beragam Penyakit Degeneratif Akibat Pola Makan. Jakarta Selatan: Laksana.

Nurkhalida. 2003. Warta Kesehatan Masyarakat. Jakarta: Departemen Kesehatan RI

Palmer, A. 2007. Simpel Guide Tekanan Darah Tinggi. Jakarta: Erlangga.

Profil Puskesmas Pembina. 2015. Laporan Jumlah Penderita Hipertensi. Palembang.

RSI Siti Khadijah. 2016. Laporan Data Jumlah Penderita Hipertensi di RSI Siti Khadijah. Palembang.

Rudianto \& Budi F. 2013. Menaklukkan Hipertensi dan Diabetes. Yogyakarta: Sakhasukam. 
Sheldon, G., dkk. 2005. Mayo Clinic Hipertensi, Mengatasi TekananDarah Tinggi. Jakarta: PT. Intisari Mediatama.

Siswono. 2001. Bahaya Kolesterol Tinggi. www.gizi.net (Diakses pada 10 Januari 2016).
Syarwendah. 2014. Hubungan Gaya Hidup dengan Tekanan Darah pada Pasien Hipertensi di Poliklinik Penyakit dalam RSI Siti Khadijah Palembang. 14(9): 23-30. World Health Organization. 2011. Noncommunicable Diseases. Genewa, Switzerland. 